appreciate the time they put into this process and the depth of their reflections about their own and each other's work. When we teach, we often reach more broadly than we do in our scholarship. This set of essays illuminates the significance of our work in the field at a level beyond that represented in a typical academic article. Also, we wish to thank these scholar-teachers for the high-quality work they do in their classrooms. They do our history of education community proud.

\title{
Defining Purpose and Process in Teaching History with Case Studies
}

\section{Fack Dougherty}

Course: Education Reform, Past and Present (mid-level survey course that typically enrolls twenty undergraduates)

Course: Cities, Suburbs \& Schools (upper-level research seminar that enrolls ten to fifteen undergraduates)

Institution: Trinity College, Hartford, Connecticut ${ }^{1}$

When the History of Education Quarterly editors invited us to contribute to this forum, they asked us to reflect on how we taught history with case studies. To jump-start our exchange, they suggested four possible purposes for teaching history in this way, which I have paraphrased below:

- To reflect on the antecedents of the so-called "new" educational policy topics (what is the long history of standardized testing?).

- To disrupt conventional beliefs with counterexamples (why did nineteenth-century science and math classrooms include so many female students?).

- To compare and contrast educational change in particular places or regions (how did the development of schooling differ in New England, the New South, or New Mexico?).

Jack Dougherty is Associate Professor of Educational Studies at Trinity College, Hartford, Connecticut, where he and his students explore the history of cities, suburbs, and schools. He teaches two courses: Education Reform-Past and Present (a mid-level survey course that typically enrolls twenty undergraduates) and Cities, Suburbs, and Schools (an upper-level research seminar that enrolls ten to fifteen undergraduates). For syllabus and course materials for the former, see http://commons.trincoll.edu/edreform; for the latter's, see http://commons.trincoll.edu/cssp. 
- To call attention to the intersection of human agency and institutional structures (how did teachers, parents, and political leaders conflict or collaborate in struggles over school reform?). ${ }^{1}$

That is an extensive list. But after reading it, my first response was a contrarian one. Flip the question upside down and ask yourself, is it even possible to teach history without case studies, broadly defined in this way? It is difficult for me to imagine a history course without antecedents, counterexamples, comparisons, and intersections, unless someone still requires students to memorize and regurgitate facts from a single-perspective textbook.

This teaching forum has taught me that historians still need a richer vocabulary to describe exactly what we mean by "teaching with case studies," because that empty phrase reveals almost nothing about what we actually do in our classrooms or, more importantly, how our students learn. We tend to use terms such as examples and case studies interchangeably, which is symptomatic of our problem. By contrast, the term case method has a specific meaning at the Harvard Business School, which provides extensive curricular materials and faculty training on guiding these student-driven discussions. ${ }^{2}$ In this essay, my aim is to enrich our discussion by emphasizing both the purpose and process of teaching history with case studies, to help us articulate more clearly both the why and how behind what we do in our courses. As we contemplate the four broader goals outlined above, I suggest that we simultaneously spell out how we design active learning exercises that guide our students to see the past in new ways, ask different kinds of questions, and create their own interpretations. Therefore, to expand on the four purposes suggested, this essay outlines four processes of teaching history with case studies:

- Sourcing and contextualizing primary documents

- Comparing and contrasting paired secondary sources

- Contributing new knowledge to local history

- Role-playing key conflicts in historical documents

Neither list is meant to be exclusive or exhaustive. Instead, the goal of stating both our purpose and process is to facilitate deeper dialogue across our respective pedagogies.

\footnotetext{
'Nancy Beadie to Jack Dougherty, e-mail, May 20, 2015 (in Jack Dougherty's possession).

2"The HBS Case Method," Harvard Business School, http://www.hbs. edu/mba/academic-experience/Pages/the-hbs-case-method.aspx; and "Case Method in Practice," C. Roland Christensen Center for Teaching and Learning, Harvard Business School, http://www.hbs.edu/teaching/case-method-in-practice/.
} 


\section{Modeling How Historians Interpret Sources}

Historians are so accustomed to interpreting sources that we often forget that our students do not necessarily come into our classes with these same skills and habits of mind. In Reading Like a Historian, Sam Wineburg and coauthors argue that good history teaching rests on two pillars: sourcing a document by actively probing its origins, audience, and intent and contextualizing the source by identifying the meaning relative to its specific time and place. ${ }^{3}$ Taking a cue from Wineburg, I recently began to model for my students during the first two weeks of my Education Reform-Past and Present undergraduate survey course how I approach primary sources. We begin with a case study of the nineteenth-century Common Schools movement; my broader goal is for students to grapple with historical actors who supported or spoke against this reform, for very different reasons, in their own words. At first, many of my students are unsure how to approach essays by advocates Horace Mann and Catherine Beecher, opponent Bishop John Hughes, and school textbooks such as the McGuffey Readers. To source these documents, I demonstrate how historians' eyes immediately leap to the bottom of a page (not the first sentence, as most novices do) to look for clues to questions such as the following: Who created this document, and when? What was the intended audience and purpose?

To help students contextualize these documents (a more challenging, ongoing task), I upload texts to the Web, where my students and I annotate them with questions and reflections that arise in our minds while reading. Currently, we comment on public domain texts from Mann, Beecher, and Hughes using Google Docs. I pose queries in the margin of the text, such as, "According to Mann, how is Massachusetts becoming more like Europe?" and "In Beecher's time, why does she need to redefine women's 'true' profession?” Assigned students either respond or call our attention to other sections of interest. Everyone in the class reads both the original text and our annotations. Indeed, the content of my annotations resembles traditional discussion questions. But embedding my questions directly into the digitized source document, where students can match them to key passages and see input

${ }^{3}$ Sam Wineburg, Daisy Martin, and Chauncey Monte-Sano, Reading Like a Historian: Teacbing Literacy in Middle and Higb School History Classrooms (New York: Teachers College Press, 2011), vi. To cultivate these skills, several history educators have drawn on the "Making Sense of Evidence" section of History Matters: The U.S. Survey Course on the Web, American Social History Project/Center for Media and Learning and the Roy Rosenzweig Center for History and New Media, http://historymatters.gmu.edu/browse/makesense/. 
from selected classmates, helps students learn how historians read and interpret cases from the past. ${ }^{4}$

\section{Pairing Sources for Sharper Contrasts}

Pairing two sources that diverge on the same historical question makes pedagogical sense because it naturally leads our students to ask how and why their interpretations vary. Subtle differences become sharper contrasts when placed side by side. A decade ago, for a History of Education Quarterly symposium on teaching Brown v. Board, I described pairing two book-length secondary sources to help my Education Reform undergraduate students compare how two different Southern black communities responded to the implementation of school desegregation in the late $1960 \mathrm{~s}^{5}$ In the current version of this comparative case study, I divide my class into two groups. Half of the class reads Silver Rights by Constance Curry, set in Sunflower County, Mississippi. This is the story of how one black family and their allies successfully won a federal lawsuit to end the local district's "freedom of choice" desegregation plan, because white landowners intimidated sharecroppers to remain in their all-black schools, rather than mix with whites. In its place, the federal court mandated that black students be integrated into Sunflower County's white schools. Meanwhile, the other half of the class reads David Cecelski's Along Freedom Road, set in Hyde County, North Carolina, where most blacks fought to keep the "freedom of choice" desegregation plan, which was thrown out as a result of the federal ruling in Mississippi. At this point, the two case studies collide.

\footnotetext{
${ }^{4}$ See the "Common Schools" section of the Education Reform syllabus (http://commons.trincoll.edu/edreform) that includes the slide presentation, "Thinking Like a Historian about the Common School Movement" (http://bit.ly/ThinkingLike-An-Historian-CSM), with links to annotated Google Docs of primary sources, such as Horace Mann, "Intellectual Education as a Means of Removing Poverty, and Securing Abundance" excerpt from "Annual Report to the Board of Education of Massachusetts for 1848," in Life and Works of Horace Mann, ed. Mary Tyler Peabody Mann, vol. 3 (Boston: Walker, Fuller, 1865), 663-70, http://catalog.hathitrust.org/Record/001067112; Catherine Beecher, The Evils Suffered by American Women and American Cbildren: Tbe Causes and the Remedy (New York: Harper \& Brothers, 1846), excerpt, http://catalog.hathitrust.org/Record/003456542; John Hughes, Committee of Catholics, Address of the Roman Catbolics to Tbeir Fellow Citizens, of the City and State of New York (New-York: Hugh Cassidy, 1840), http://archive.org/details/addressofromanca00newy. See also William Holmes McGuffey and Stanley W. Lindberg, "The Little Chimney Sweep (First Reader, 1836-1857 Editions)," in The Annotated McGuffey: Selections from the McGuffey Eclectic Readers, 18361920 (New York: Van Nostrand Reinhold, 1976), 16-18.

For the original teaching essay, see Jack Dougherty, "Making Sense of Multiple Interpretations," History of Education Quarterly 44, no. 1 (2004): 105-8.
} 
After both halves read their respective books, I bring them together for a jigsaw group exercise. First, students review their book with classmates who read the same text. Next, we shift to mixed groups where pairs of students summarize their books for pairs of students who read the other title. All students work from a common discussion guide, which outlines key historical actors and poses comparative questions, such as, "What were the conditions of black schools in each community?" and "How did activists in each community define the goals of their struggle?"6

Gradually, students contextualize that "freedom of choice" had different meanings in these two communities. In Sunflower County, choice was a sham because the black schools were poorly resourced, with minimal instruction beyond primary grades. But Hyde County had a long tradition of better-resourced black schools with college-educated teachers, and choice was the only viable strategy to protect them from closure in the face of a white-dominated, one-way desegregation plan. Pairing these complementary case studies, and organizing the class for students to teach the essentials to one another, helps them to learn more deeply than they would by reading either book alone. The exercise highlights not only regional differences, but also challenges students to question their historical preconceptions about school integration, and to focus more on the intersections of power over the implementation of educational reforms.

\section{Contributing Knowledge to Local History}

When teaching my national-level Education Reform survey course, I intentionally assign cases that exemplify selected key concepts in U.S. educational history, and some students tell me that initially they have difficulty relating to the arcane language or the unfamiliar circumstances of distant peoples. (I acknowledge that my colleagues who teach history about earlier time periods and outside of the United States face larger challenges than me.) But this is a fundamental reason we learn history. The past makes our present seem strange, I tell my students, and challenges our present-day assumptions about how things have always worked. Gradually, as we work together to interpret sources, my students begin to share some "aha" moments of historical understanding across distant times and places. This is the value of faraway case studies.

\footnotetext{
${ }^{6}$ See the Curry-Cecelski exercise in the Education Reform syllabus cited above, with a link to the reading guide at http://commons.trincoll.edu/edreform/ resources/curry-cecelski-reading-guide.
} 
But there is also an argument for teaching history with nearby case studies, as I do in my Cities, Suburbs, and Schools seminar, which has different goals for student learning. This undergraduate seminar is grounded in the Greater Hartford region of Connecticut, one of the most economically and racially polarized metropolitan areas of the northeastern United States, where Trinity College is located. Even though most students grew up outside of the state, they reside in Hartford for most of their four years, and as young adults, often struggle to make sense of the inequalities they encounter in their daily lives. Although this seminar is not exclusively historical, the most obvious case study - and often, the most meaningful-addresses the one where you currently live. One way to use the past to challenge students about their present-day reality is to investigate what the City of Hartford and its suburbs looked like over a century ago. We read journalists' reports from the 1870s that describe Hartford as "the richest city in the nation," and early twentieth-century accounts that praise the greatness of the city school system and portray suburban towns as woefully inadequate. ${ }^{7}$ These sources from the past flip my students' understanding of their present upside down, and prompt us to ask such questions as "What caused the city to decline?" and "What sparked the success of the suburbs?" When my students and I think further outside our present-day boxes, we sometimes ponder, "Might it be possible for the central city to rise again?"

A second reason for teaching nearby case studies is the potential to directly contribute to our present-day community's understanding of local history. For two years, I have partnered with Clarissa Ceglio, an editor of the statewide public history website ConnecticutHistory.org, to create a seminar writing assignment for students to contribute essays on inequality and civil rights that had not yet been addressed in their digital publication. Clarissa visited our seminar to frame the assignment and the public history audience, and continued to coach and comment on students' drafts online using Google Docs. I guided my students on identifying and interpreting relevant source materials on selected topics. All students write, revise, and post their final essays on our seminar website, and a third of the students have continued to revise their work (typically after the semester has ended) to meet the higher standards for publication on the ConnecticutHistory.org site. Student essays have explored early African-American migration into Hartford, housing and schooling segregation, and civil rights strategies to create change, such as Connecticut's 1965 constitutional amendment for equal

${ }^{7}$ Jack Dougherty, "Investigating Spatial Inequality with the Cities, Suburbs, and Schools Project," in On the Line (Hartford, CT: Trinity College, 2015), http://epress.trincoll.edu/ontheline2015/chapter/investigating-spatial-inequality/. 
education, voluntary busing for integration, and the 1989 Sheff v. O'Neill school desegregation case. ${ }^{8}$

To be sure, individual students working on faraway case studies can always submit their work to publications in that field. But nearby case studies make the pedagogical process easier to organize, especially when partnering with a local history organization, with a greater likelihood of collective success. Typically, students spend hours on writing assignments that are ultimately read only by their professor, so contributing historical knowledge to a broader community adds value to everyone's educational experience. When Amanda Gurren reflected on the multiple revisions she made to publish her essay, she emphasized how collaborating with ConnecticutHistory.org elevated her own view and expectations of herself. "You felt more like a contributor or colleague rather than just a student handing in an assignment," she explained. "We felt like we were working with people rather than for them." Designing a local history case study assignment not only has the potential to incentivize students to improve their own writing, but also to view themselves and their peers as contributors to the education of others.?

\section{Role-playing with Historical Documents}

Another case study teaching strategy is role-playing simulations with historical source documents, an approach that I informally adopted on a small scale-then stopped using-in the Education Reform course several years ago. My simplistic approach was to set up a half-hour classroom debate over a hypothetical proposal to establish Common Schools in a mythical town in the mid-nineteenth century. Students were divided into three teams with very different responses to the plan: (1) local supporters of Horace Mann who resided in the central town where they proposed to build a new school, (2) Catholic immigrants who also lived in the central town but who were skeptical of Protestant

\footnotetext{
${ }^{8}$ See published student essays at "Trinity College Students Call Attention to Histories of Inequality," ConnecticutHistory.org, http://connecticuthistory.org/trinitycollege-students-call-attention-to-histories-of-inequality/.

${ }^{9}$ For further details on the pedagogical process, see Elaina Rollins, Clarissa Ceglio, and Jack Dougherty, "Writing Greater Hartford's Civil Rights Past with ConnecticutHistory.org," Connecticut History Review 53, no. 2 (Fall 2014), 220-26, reprinted with permission in Dougherty and contributors, On the Line, http://epress. trincoll.edu/ontheline2015/chapter/connecticut-history-review/. For a video on the process and student reflections at ConnecticutHistory.org programs, see Make Life Collaborative, 2013, http://youtu.be/NuWg9Jrkrpw.
} 
dominance, and (3) German farmers who lived farther away from the central town and would lend support only if their native language were taught. Based on students' reading of this general conflict in Carl Kaestle's Pillars of the Republic, I gave them a few minutes to organize their talking points, select a representative to deliver one-minute speeches to clarify what they favored or opposed in the plan, and coached them to be as historically authentic as possible during the informal debate that followed. ${ }^{10}$ During the years we did this quick simulation in class, most students deepened their grasp of the underlying conflict and understood how a proposal to establish a centralized school, which seemed quite innocuous to most at first, became controversial in that context. Some students demonstrated a closer reading of the text and/or more theatrical flair than others.

But I always questioned whether this hypothetical mini-simulation was worth the class time, and knew that creating a full-scale version would necessitate chopping something else out of the syllabus. The full title of my course is Education Reform-Past and Present, and one of my primary goals is to help my students to recognize parallels, as well as the dangers of presentist thinking, in contemporary debates over school reform. Furthermore, Connecticut's state capitol is located just over a mile from our classroom, and hundreds of people were crowding into legislative hearings to debate the role of public education in shaping our culture and economy, and whether it was best to centralize or decentralize traditional, magnet, and charter schools. So rather than scale up my historical simulation, I decided to cut it out of this course. Rather than playing more make-believe history, pairs of students went to public hearings and school board meetings to report on educational history as it was being made.

Moving in the opposite direction from me was Mark Carnes, a historian from Barnard College, and his network of colleagues who have built an expanding collection of role-playing simulations known as Reacting to the Past. These full-scale simulations are much more sophisticated than my half-hour hypothetical exercise. A typical Reacting game on the French Revolution of 1789, women's suffrage and labor strikes in New York in 1913, or the partition of the British Indian Empire in 1947 may last an entire month in the classroom. Teams of students collaborate and compete to achieve the interests of their assigned historical roles by reading hundreds of pages of source materials

\footnotetext{
${ }^{10}$ Students engaged in this brief role-play after reading most of Pillars of the Republic paying particular attention to chapter 7 on resistance to reform. Carl Kaestle, Pillars of the Republic: Common Schook and American Society, 1780-1860 (New York: Hill and Wang, 1983).
} 
in the game publications, which they mine for arguments to include in their essays and speeches delivered in the classroom.

Peer-reviewed Reacting simulations have been taught in over three hundred colleges, and perhaps most interestingly, in many classes outside of history departments. Skimming through the "Big List of Reacting Games" on the organization's website, I look for those most relevant to educational history. One that touches on a recent chapter is Kansas, 1999: Evolution and Creation Science, which focuses on science curriculum and politics surrounding the state board of education, and is coauthored by David Henderson, my retired colleague from the Chemistry Department at Trinity College. More games of interest to educational historians, currently in prototype format, include Trading Races (on racial diversity and admissions at the University of Michigan in 2003) and Title IX and the American University. Additional games currently in the concept stage explore the conflict between Booker T. Washington and W. E. B. Du Bois, the road to Brown $v$ Board of Education, and the crisis at Central High School in Little Rock, Arkansas. ${ }^{11}$

The Reacting games spark my interest in possibly reintroducing this pedagogy into my educational history course, but they also raise more questions. Given that the published games focus primarily on major historical conflicts, I wonder if certain episodes lend themselves better to this format, such as debates over Common Schools or progressive education reformers. Or might it be morally inappropriate to create games that role-play the tragedies of real people, such as forced segregation of African Americans or the cultural annihilation of Native American students? Since these games thrive on student competition, might the need to "win" against opponents overwhelm other values that we seek to cultivate, such as more empathetic understandings of people whose perspectives differ from our own? Several faculty who have shared my doubts also describe the Reacting games as the most transformative experience of their teaching careers. ${ }^{12}$ Readers of this journal should look at Carnes's recent book, Minds on Fire, both for his rich observations and interviews with students and faculty who participated in these games, and also his insightful historical analysis of classroom learning and student culture in American higher education. By far, it is the best book I have read on these topics in many years. ${ }^{13}$ Of course, Carnes would only be partly satisfied if you read his book. His ultimate

\footnotetext{
"At this writing, the "Big List of Reacting Games" included over ten published games, over seventy-five working models and prototypes, and seventy more at the conceptual stage. Reacting to the Past, Barnard College, accessed August 2015, https://reacting.barnard.edu/.

${ }_{12}$ James M. Lang, "Being Nehru for 2 Days," The Chronicle of Higher Education, 21 July 2014, http://chronicle.com/article/Being-Nehru-for-2-Days/147813/.

${ }^{13}$ Mark C. Carnes, Minds on Fire: How Role-Immersion Games Transform College (Cambridge, MA: Harvard University Press, 2014).
} 
goal is to entice us to play the game, perhaps while attending a Reacting summer conference.

While scholarly essays typically conclude that we need more research, this one ends on a different point: we need more thoughtful teaching, accompanied by insightful reflection and writing about our purposes and processes, and richer accounts of what we and our students have learned. Our current lack of a shared vocabulary on teaching and learning should not surprise anyone in academia, where our institutional and individual priorities tend to focus on the number of publications we produce, not the depth of student engagement in our classrooms. But this absence should bother historians of education. Given that we specialize in the dynamics of schooling, and pay close attention to the meanings of words, we still seem uncomfortably challenged, as a profession, when asked to describe how teaching and learning actually happens in our classrooms. No doubt, it is uncommon to be asked by an academic journal to thoughtfully describe our own pedagogy, and to subject these words to close review from our peers. Historians of education simply need more practice. We should improve how we document and describe learning in our own classrooms. Perhaps, we need to take some lessons from ethnographers.

\title{
Case Study as Common Text: Collaborating in and Broadening the Reach of History of Education
}

\author{
Ansley T. Erickson
}

Course: Harlem Stories courses, within the Educating Harlem project

Institution: Teachers College, Columbia University

A graduate school of education contains a wide range of disciplinary models for the training of scholars and practitioners. I encounter these models as they come up in conversation with colleagues and students,

Ansley T. Erickson is Assistant Professor, History and Education, Teachers College, Columbia University (erickson@tc.columbia.edu). She is the author of Making the Unequal Metropolis: Scbool Desegregation and Its Limits (Chicago: University of Chicago Press, 2016). Thanks to the Institute for Urban and Minority Education, the Columbia Center for Digital Research and Scholarship, and TC Provost Tom James for support of Educating Harlem. 